\title{
RELATIONSHIP BETWEEN THE QUALITY OF HIGHER EDUCATION AND BALKAN COUNTRIES' COMPETITIVENESS
}

Dr. Tanja Stanišić, University of Kragujevac, Faculty of Hotel Management and Tourism in Vrnjačka Banja, Serbia, E-mail: tanja.stanisic@kg.ac.rs

Dr. Miljan Leković, University of Kragujevac, Faculty of Hotel Management and Tourism in Vrnjačka Banja, Serbia, E-mail: m.lekovic@kg.ac.rs

Dr. Lazar Stošić, The Association for the Development of Science, Engineering and Education, Serbia E-mail: lazarstosic@yahoo.com

ARTICLE INFO

Original Research

Received: October, 25.2019.

Revised: November, 15.2019.

Accepted: November, 25.2019.

doi: 10.5937/IJCRSEE1903049S

UDK

$378.014 .5(497)$

Keywords:

Balkan countries,

competitiveness,

development,

education,

higher education.

\begin{abstract}
A B S T R A C T
The main purpose of the research is to determine the link between the quality of higher education and the competitiveness level of the Balkan countries. In addition, the goal is to identify critical factors in the field of higher education that require improvement. The methods used in the paper are comparative analysis, descriptive statistics, correlation analysis, cluster analysis and benchmarking analysis. The results of the research point to the fact that there is no high positive correlation between the quality of higher education and the competitiveness level of the Balkan countries. However, it is noticed that the Balkan countries record better results when it comes to higher education than the level of competitiveness. Apart from the necessity of improving certain domains of higher education, the priority of the education policy and development policy makers in the Balkan countries should be the utilization of the results achieved in education in the function of improving competitiveness.
\end{abstract}

\section{INTRODUCTION}

One of the engines of economic development in social, community and individual level is human capital. "In developed, as well as in developing countries, the key engine for economic growth has been the group of people with the generally high level of education, motivation and dedication" (Balkyte and Tvaronavičiene, 2010, p. 349). Also, human resources make up the most valuable asset of modern organizations and the only real basis for creating competitive advantage (Petrović and Živković, 2017, p. 88). The process of globalisation emphasizes knowledge as the basic value and "requires educated people who will be able to adapt

Corresponding Author

Dr. Tanja Stanišić, University of Kragujevac, Faculty of Hotel Management and Tourism in Vrnjačka Banja, Serbia, E-mail: tanja.stanisic@kg.ac.rs

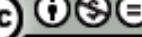

This work is licensed under a Creative Commons Attribution - NonCommercial - NoDerivs 4.0. The article is published with Open Access at www.ijcrsee.com
(C) 2019 IJCRSEE. All rights reserved.

to social, economic, and cultural changes" (Krstić et al., 2015, p. 750; Hebibi et al., 2019, p. 118). "Knowledge is the certain source of competitive advantage for business systems and the key factor of economic development of any country in terms of the dynamic competitive struggle in the global market" (Krstić and Stanišić, 2013, p. 152; Radovanović and Rendulić, 2017, p. 102). On the other hand, "higher education is of crucial importance in the development of production systems, implementation of new technologies and management systems at the point where strategic decisions are taken in a country" (Keser, 2015, p. 59; Stošić, 2015, p. 113). Knowledge and higher education are the strategic factors that "have produced important changes in what is now framed as the education industry" (Sum and Jessop, 2013).

Nowadays, in the era of knowledge economy, there is a close connection between knowledge and higher education and economic performances on the micro and macro level. Education is indeed a highly relevant topic for international development and is considered 
"both as a development goal and a means to its achievement" (Cremin and Nakabugo, 2012). Education has been regarded for decades as valuable for economic development, but this perspective evolved to "include dimensions of social, economic and human development, such as health, education, gender, political and environmental considerations, linked to participation in social, political, economic and cultural life" (Persaud, 2017). Higher education is, therefore, essential for human development (Schofer and Meyer, 2005) and is a major source of societal transformations by empowering "students to act as change agents in their future professional and societal environments" (Fonseca et al., 2018).

Predictions for the future indicate that this millennium, in the field of economics, will be marked by the dominance of the competitive advantages based on technology, skills and abilities (Stanišić and Leković, 2018; Đurić et al., 2018). When it comes to skills and abilities, adult education is emerging as an important element of competitiveness and a fundamental premise of economic growth and development in times of rapid changes and global movements. Education is seen as central to economic competitiveness, the reduction of poverty and inequality, and environmental sustainability (Lauder et al., 2006). Investment in education strengthens the competitiveness of the economy, which is very important for the struggle against the crisis and the inclusion of one country in the international distribution of labour. Researchers underlined the importance of the role that the national funding mechanism plays in reforms and designing a competitive industry of higher education (Cretan and Gherghina, 2015). On the other hand, "higher education is being regarded as a terrain increasingly characterised by privatisation, profit making and competitiveness" (Mayo, 2009 , p. 95). The rapid and dynamic changes which characterize modern society do not overlook the area of higher education.

The only preferred way of adjusting higher education to changes is an adequately conceived reform process. Slow implementation of reforms in key areas of education can lead to limited economic growth and stagnation of the country's competitiveness on a global level. As part of the reform measures, many authors propose measures to improve the competitiveness of the higher education system in their research (Kovaleva et al., 2015), such as increased transparency (Van der Wende, 2000) and measures of evaluation and surveying of competitiveness of higher education (Kabók et al., 2013; Stonkiene et al., 2016). Competitive higher education is the first step towards the use of achievements in this field in the function of improving the country's global competitiveness.

It could be seen that many researches, publications, scientific papers are dedicated to higher education and its role in overall development. Also, correlation between the quality of the higher education system and the level of competitiveness of the country is the subject of numerous researches. Pavlin and Svetlicic (2012), exploring the example of nineteen European countries, conclude that more competitive countries have developed higher education systems with more practically oriented studies and a higher workload. Sekuloska (2014) finds very strong positive relationship between the quality of the education system and competitiveness in the case of advanced European Union members. Keser (2015) researches the effects of higher education on the global competitiveness of the countries of the European Union and the Middle East, and emphasizes that countries that attach great importance to higher education are also countries with a high level of competitiveness. Aleksejeva (2016) concludes that "there is a high degree of correlation between higher education and the global competitiveness of the Baltic and Nordic countries". Şener and Sarıdoğan (2011) stand higher education as one of the key resources for the development of science-technology-innovation based competitiveness. Author Lane (2012) emphasizes that "as countries move into more advanced economic stages, higher education becomes increasingly important".

In addition to numerous studies that emphasize the positive link between the quality of higher education and competitiveness and empirically confirm this relationship on the sample of developed countries, not so many authors research the interdependence between the quality of higher education and competitiveness in developing countries. Therefore, the above mentioned interdependence in the Balkan countries is being examined in the paper. The purpose of this research is to assess the position of the Balkan countries towards the obtained level of higher education quality. The objective of the research is to identify the interdependence between the quality of higher education and the achieved level of competitiveness of the Balkan countries. The results of the research 
are divided into several sections. The analysis of the relative position of the Balkan countries according to indicators of the quality of higher education, among themselves and in relation to the countries of good practice, is carried out in the section dedicated to cross-country comparison. The next section is devoted to the examination of the interdependence between higher education and competitiveness, or the correlation between the Global Competitiveness Index (GCI) and the "Higher education and training" pillar and its eight indicators. The third section of the results deals with examining the homogeneity of the Balkan countries according to the quality of higher education. The Balkan countries are grouped into two clusters according to the results achieved in this field. Finally, the last section is intended for systematization of those indicators that require improvement, in order that the increased quality of the higher education system contributes to the higher level of competitiveness of the analysed group of countries. In accordance with the defined purpose and objectives of the research, the authors start from the basic assumption that there is a high positive correlation between the quality of higher education and competitiveness of the Balkan countries.

\section{MATERIALS AND METHODS}

The information base of the research is "The Global Competitiveness Report 2017-2018" of the World Economic Forum (WEF). The report presents the results of the Global Competitiveness Index which tracks the performance of 137 countries on 12 pillars of competitiveness. Although there is some controversy concerning the reliability of international Global Competitiveness Indexes, due to data collection and reporting issues in some countries, the conjoint use of differing underlying methodological approaches, support the use of those indexes "as a set of reliable and useful performance indicators" (Fonseca and Lima, 2015). The main subject of the analysis is the fifth pillar of the GCI, "Higher education and training", which consists of eight indicators (WEF, 2017, p. 346): "Secondary education enrollment (I1), Tertiary education enrollment (I2), Quality of the education system (I3), Quality of math and science education (I4), Quality of management schools (I5), Internet access in schools (I6), Local availability of specialized training services (I7), Extent of staff training
(I8)".

The research is carried out on a sample of nine Balkan countries (Albania, Bosnia and Herzegovina, Bulgaria, Croatia, Greece, Montenegro, Romania, Serbia and Slovenia). The research does not cover the European part of Turkey, as well as Macedonia, for which does not have available data in the latest WEF report.

The methods applied in the paper are comparative analysis, descriptive statistics, correlation analysis, cluster analysis and benchmarking analysis. The relative position of the analysed Balkan countries in terms of the GCI, "Higher education and training" pillar and mentioned indicators is examined by the comparative analysis. For the purposes of further research, the minimum, maximum and mean values of analysed indicators were determined by the descriptive statistics. In addition, the descriptive statistics also show the degree of variability of indicators in a selected group of countries. The correlation analysis examined the interdependence of the "Higher education and training" pillar and its indicators and the competitiveness of the Balkan countries measured by the GCI score. By the cluster analysis, Balkan countries are divided into two groups according to the achieved values of indicators, which enables identification of countries with the lowest level of performance. Finally, critical indicators that require improvement with the aim of achieving a higher level of education quality and competitiveness are highlighted by the benchmarking analysis, where the benchmark is the average value of indicators of the selected group of countries.

\section{RESULTS AND DISCUSSIONS}

The results of the research are grouped into four segments:

a) Cross-country comparison,

b) Examining the interdependence between education and competitiveness,

c) Examining the homogeneity of the Balkan countries, according to the quality of education, and

d) Systematization of critical indicators within "Higher education and training" pillar in the Balkan countries.

\subsection{Cross-country comparison}

In order to evaluate the relative position of the Balkan countries towards the achieved 
level of competitiveness and the quality of higher education, Table 1 presents the values of the GCI, the "Higher education and training" pillar and indicators within this pillar in the Balkan countries, as well as the average values of the observed index, pillar and indicators for the Balkan countries and for total of 137 world countries whose results are measured by the WEF in its last report.

Table 1. Score of the GCI, "Higher education and training" pillar and indicators within the "Higher education and training" pillar (2017)

\begin{tabular}{|c|c|c|c|c|c|c|c|c|c|c|}
\hline & 包 & 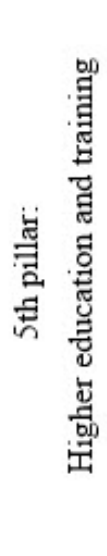 & 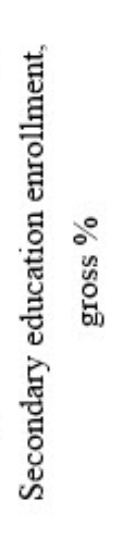 & 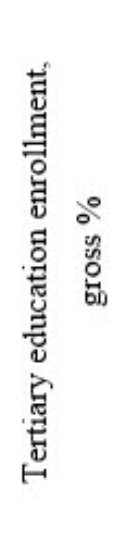 & 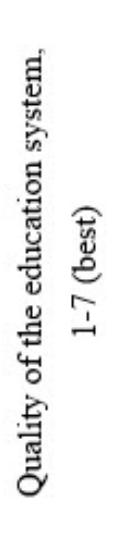 & 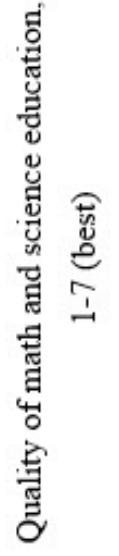 & 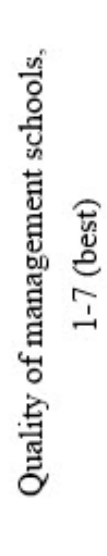 & 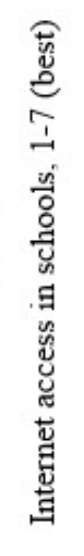 & 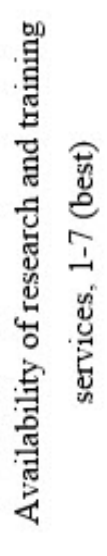 & 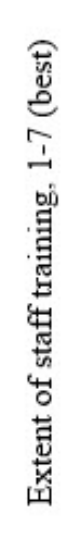 \\
\hline Albania & 4.18 & 4.77 & 95.77 & 58.11 & 4.29 & 4.30 & 4.09 & 5.27 & 4.01 & 3.83 \\
\hline \multicolumn{11}{|l|}{ Bosnia and } \\
\hline Herzegovina & 3.87 & 3.98 & 88.68 & 47.60 & 2.37 & 3.44 & 3.25 & 3.88 & 3.57 & 3.06 \\
\hline Bulgaria & 4.46 & 4.62 & 99.02 & 73.93 & 3.39 & 3.82 & 3.44 & 4.45 & 3.73 & 3.34 \\
\hline Croatia & 4.19 & 4.54 & 98.22 & 69.05 & 2.91 & 4.30 & 3.84 & 3.44 & 4.19 & 3.14 \\
\hline Greece & 4.02 & 4.87 & 106.50 & 113.87 & 3.05 & 4.39 & 4.08 & 3.60 & 3.96 & 3.72 \\
\hline Montenegro & 4.15 & 4.54 & 90.34 & 55.34 & 3.80 & 4.27 & 4.12 & 4.13 & 4.08 & 3.45 \\
\hline Romania & 4.28 & 4.41 & 92.25 & 53.22 & 2.80 & 4.96 & 3.27 & 4.07 & 4.22 & 3.30 \\
\hline Serbia & 4.14 & 4.55 & 96.67 & 58.29 & 3.27 & 4.82 & 4.01 & 3.88 & 4.11 & 3.42 \\
\hline Slovenia & 4.48 & 5.37 & 110.67 & 82.93 & 4.04 & 5.38 & 4.39 & 5.38 & 4.66 & 4.15 \\
\hline $\begin{array}{l}\text { Average of } \\
\text { the Balkan countries }\end{array}$ & 4.20 & 4.63 & 97.57 & 68.04 & 3.32 & 4.41 & 3.83 & 4.23 & 4.06 & 3.49 \\
\hline World average & 4.30 & 4.32 & 86.92 & 43.38 & 3.77 & 4.05 & 4.30 & 4.26 & 4.45 & 4.04 \\
\hline
\end{tabular}

Legend: $\square$ Countries with the lowest value of index/pillar/indicator
Countries with the highest value of index/pillar/indicator

\section{Source: World Economic Forum}

The achieved level of competitiveness in the Balkan countries was considerably lower than the achieved level of competitiveness in the countries that were global leaders in 2017 (Switzerland and the United States, with a score of the GCI of 5.9) (WEF, 2017). Compared to the average value of the GCI for the Balkan countries, three countries (Bulgaria, Romania and Slovenia) recorded higher value of the GCI than the average of this group of countries. Only two countries, Bulgaria and Slovenia, recorded higher value of the GCI than the world average.

When the value of "Higher education and training" pillar was considered, and taking into account the fact that at the global level, Singapore recorded the best score of 6.3 , while the best ranked country at the level of European countries was Finland (score of 6.2) in 2017, it can be concluded that all the Balkan countries, except Slovenia, recorded the results that are much lower than the best world and European practices in this field. Three countries, Albania, Greece and Slovenia, recorded higher value of this pillar compared to the average value for the group of Balkan countries. However, eight out of nine analyzed Balkan countries recorded higher value of pillar in relation to the world average. The lower value of "Higher education and training" pillar compared to the 
world average was recorded only in Bosnia and Herzegovina.

When the achieved values of indicators within the "Higher education and training pillar" in the Balkan countries were compared, it was concluded that Bosnia and Herzegovina was a country that recorded minimum values of almost all indicators in 2017. Namely, Bosnia and Herzegovina was not the worst ranked only when it comes to "Internet access in schools" indicator. The minimum value of this indicators was recorded in Croatia. On the other hand, Slovenia was a leader in almost all observed parameters. In addition to being the best-ranked Balkan country in terms of global competitiveness, it recorded the highest values of almost all other observed indicators, except "Tertiary education enrollment" and "Quality of the education system". The highest value of "Tertiary education enrollment" indicator was achieved by Greece, while Albania recorded the highest value of "Quality of the education system" indicator.

It should be noted that the average values of the "Secondary education enrollment" indicator and the "Tertiary education enrollment" indicator in the Balkan countries were higher than the world average, and that all observed Balkan countries recorded higher value of these indicators in relation to the world average. The Balkan countries also recorded higher average value of the "Quality of math and science education" indicator compared to the world average. The average value of the remaining five analyzed indicators for the group of Balkan countries was lower than the world average. This fact points to the field of higher education in the Balkan countries that require improvement.

For the purpose of more complete analysis, Table 2 gives an overview of the descriptive statistics of the observed indicators. In general, the Balkan countries recorded a significantly higher average value of the "Secondary education enrollment" indicator, compared to the "Tertiary education enrollment". Also, the "Quality of math and science education" was at a higher level than the "Quality of management schools". The availability of research and training services is better assessed than the extent of staff training. The calculated value of the variation coefficient indicates that the Balkan countries recorded the highest variability according to "Tertiary education enrollment" indicator. On the other hand, the Balkan countries were fairly balanced when it comes to the values of "Secondary education enrollment" and "Availability of research and training services" indicators.

Table 2. Descriptive statistics (Balkan countries)

\begin{tabular}{|c|c|c|c|c|c|c|}
\hline & $\mathrm{N}$ & Minimum & Maximum & Mean & $\begin{array}{c}\text { Std. } \\
\text { Deviation }\end{array}$ & $\begin{array}{c}\text { Variation } \\
\text { Coefficient } \\
(\%)\end{array}$ \\
\hline Secondary education enrollment, gross $\%$ & 9 & 88.68 & 110.67 & 97.56 & 7.22441 & 7.41 \\
\hline Tertiary education enrollment, gross $\%$ & 9 & 47.60 & 113.87 & 68.03 & 20.46398 & 30.08 \\
\hline Quality of the education system, 1-7 (best) & 9 & 2.37 & 4.29 & 3.32 & 0.62358 & 18.78 \\
\hline $\begin{array}{l}\text { Quality of math and science education, 1-7 } \\
\text { (best) }\end{array}$ & 9 & 3.44 & 5.38 & 4.40 & 0.58574 & 13.31 \\
\hline Quality of management schools, 1-7 (best) & 9 & 3.25 & 4.39 & 3.83 & 0.41267 & 10.77 \\
\hline Internet access in schools, $1-7$ (best) & 9 & 3.44 & 5.38 & 4.23 & 0.68502 & 16.19 \\
\hline $\begin{array}{l}\text { Availability of research and training ser- } \\
\text { vices, } 1-7 \text { (best) }\end{array}$ & 9 & 3.57 & 4.66 & 4.05 & 0.30961 & 7.64 \\
\hline Extent of staff training, $1-7$ (best) & 9 & 3.06 & 4.15 & 3.49 & 0.34939 & 10.01 \\
\hline Valid N (listwise) & 9 & & & & & \\
\hline
\end{tabular}

Source: Authors' calculation

Compared to world practice (Annex 1), the Balkan countries recorded significantly better results of all observed indicators compared to the minimum values recorded in the world. However, the Balkan countries are far behind the best world practice (maximum values of indicators) in all segments of higher education, except for the "Tertiary education enrollment" indicator. Namely, the maximum value of this indicator on the world level was recorded in Greece. Expectedly, the variability of the values of all observed indicators measured by the coefficient of variation was 
higher on a global level than in the group of Balkan countries.

\subsection{Examining the interdependence between higher education and competitiveness}

In order to examine the potential interdependence between the quality of higher education and the level of competitiveness of the Balkan countries, Table 3 gives an overview of Spearman's rank correlation coefficient between the values of the analysed indicators and the GCI. Table 3 also provides an overview of the correlation coefficients between the values of the analysed indicators and the "Higher education and training" pillar.

The following scale was used in interpreting the values of correlation coefficients: the values of correlation coefficients $\leq 0.35$ represent low or weak correlation, the values of correlation coefficients from 0.36 to 0.67 represent moderate correlation and the values of correlation coefficients from 0.68 to 1 represent strong or high correlation where the values of correlation coefficients $\geq 0.9$ indicate very high correlation (Weber and Lamb, 1970; Mason et al., 1983; Taylor, 1990).

Table 3. Values of the Spearman's rank correlation coefficient

\begin{tabular}{|c|c|c|c|}
\hline & & & education and \\
\hline & & $G C I$ & training \\
\hline \multirow[t]{2}{*}{$G C I$} & Correlation Coefficient & 1.000 & 0.335 \\
\hline & Sig. (2-tailed) & . & 0.379 \\
\hline \multirow[t]{2}{*}{ Higher education and training } & Correlation Coefficient & 0.335 & 1.000 \\
\hline & Sig. (2-tailed) & 0.379 & \\
\hline \multirow[t]{2}{*}{ Secondary education enrollment } & Correlation Coefficient & 0.483 & $0.837(* *)$ \\
\hline & Sig. (2-tailed) & 0.187 & 0.005 \\
\hline \multirow[t]{2}{*}{ Tertiary education enrollment } & Correlation Coefficient & 0.317 & $0.845(* *)$ \\
\hline & Sig. (2-tailed) & 0.406 & 0.004 \\
\hline \multirow[t]{2}{*}{ Quality of the education system } & Correlation Coefficient & 0.400 & $0.720(*)$ \\
\hline & Sig. (2-tailed) & 0.286 & 0.029 \\
\hline \multirow[t]{2}{*}{ Quality of math and science education } & Correlation Coefficient & 0.393 & 0.433 \\
\hline & Sig. (2-tailed) & 0.295 & 0.245 \\
\hline \multirow[t]{2}{*}{ Quality of management schools } & Correlation Coefficient & 0.217 & $0.720(*)$ \\
\hline & Sig. (2-tailed) & 0.576 & 0.029 \\
\hline \multirow[t]{2}{*}{ Internet access in schools } & Correlation Coefficient & 0.586 & 0.429 \\
\hline & Sig. (2-tailed) & 0.097 & 0.250 \\
\hline \multirow[t]{2}{*}{$\begin{array}{l}\text { Availability of research and training } \\
\text { services }\end{array}$} & Correlation Coefficient & 0.583 & 0.151 \\
\hline & Sig. (2-tailed) & 0.099 & 0.699 \\
\hline \multirow[t]{2}{*}{ Extent of staff training } & Correlation Coefficient & 0.250 & $0.870(* *)$ \\
\hline & Sig. (2-tailed) & 0.516 & 0.002 \\
\hline
\end{tabular}

Legend: $* *$ Correlation is significant at the 0.01 level (2-tailed)

* Correlation is significant at the 0.05 level (2-tailed)

\section{Source: Authors' calculation}

Observing the relationship between the analysed indicators of the quality of higher education within the "Higher education and training" pillar and the GCI, it was concluded that there was a positive correlation. However, there was no high positive correlation between the values of any indicator and the GCI. The low positive correlation was recorded between the GCI and three indicators ("Tertiary education enrollment", "Quality of management schools" and "Extent of staff training"). The moderate positive correlation was recorded between the GCI and the remaining five indicators. The results obtained were not statistically significant.

In contrast, there was a high positive 
statistically significant correlation between the "Higher education and training" pillar and its five indicators ("Secondary education enrollment", "Tertiary education enrollment", "Quality of the education system", "Quality of management schools", "Extent of staff training").

In order to conduct a more detailed analysis of the relationship between higher education and competitiveness of the analysed group of countries, but with the control of other factors that influence on competitiveness, the partial correlation between the value of the "Higher education and training" pillar and the GCI was calculated (Table 4). The WEF groups all factors that impact on competitiveness into 12 pillars. The values of the other 11 pillars in the analysed Balkan countries (in addition to the "Higher education and training" pillar) were taken for control variables (WEF, 2017).

Table 4. Partial correlation

\begin{tabular}{|c|c|c|c|}
\hline & Control Variables & & GCI \\
\hline \multirow{7}{*}{$\begin{array}{l}\text { Higher } \\
\text { education } \\
\text { and } \\
\text { training } \\
\text { pillar }\end{array}$} & \multirow{3}{*}{$\begin{array}{l}\text { Pillars within Basic } \\
\text { requirements } \\
\text { subindex }\end{array}$} & Correlation & 0.154 \\
\hline & & Significance & 0.805 \\
\hline & & (2-tailed) & \\
\hline & \multirow{2}{*}{$\begin{array}{l}\text { Pillars within Effi- } \\
\text { ciency enhancers sub- } \\
\text { index }\end{array}$} & Correlation & 0.598 \\
\hline & & $\begin{array}{l}\text { Significance } \\
\text { (2-tailed) }\end{array}$ & 0.102 \\
\hline & \multirow{2}{*}{$\begin{array}{l}\text { Pillars within Innova- } \\
\text { tion and sophistica- } \\
\text { tion factors subindex }\end{array}$} & Correlation & -0.125 \\
\hline & & $\begin{array}{l}\text { Significance } \\
\text { (2-tailed) }\end{array}$ & 0.790 \\
\hline
\end{tabular}

Source: Authors' calculation

Weak positive correlation, or correlation coefficient of 0.154 was obtained by calculating the partial correlation between the "Higher education and training" pillar and the GCI in the Balkan countries, with the control of the impact of the values of pillars within the "Basic requirements subindex". Correlation coefficient of 0.598 , or moderate positive correlation was obtained when the values of pillars within the "Efficiency enhancers subindex" were used as control variables. It was concluded that the "Higher education and training" pillar and the GCI in the Balkan countries was negatively correlated, or the value of the correlation coefficient was -0.125 , using the values of indicators within the "Innovation and sophistication factors subindex" as control variables. The results obtained were not statistically significant.

\subsection{Examining the homogeneity of the Balkan countries according to the quality of education}

The Balkan countries were grouped into two relatively homogeneous groups, according to the realized values of the indicators within the "Higher education and training" pillar by the cluster analysis. The k-means cluster analysis is used in the paper. K-means clustering algorithm performs minimization of the variation between clusters and thus implement segmentation variables. By using a non-hierarchical cluster analysis, certain units can be classified into groups that are linked according to certain observation variables. In this way, homogeneous groups that are heterogeneous to each other are obtained (Puška \& Beganović, 2016). Table 5 shows the final cluster centres. It can be concluded that the countries belonging to cluster 2 had relatively weaker performance when it comes to the quality of higher education in relation to the countries belonging to cluster 1 .

Table 5. Final Cluster Centers

\begin{tabular}{lcc}
\hline & \multicolumn{2}{c}{ Cluster } \\
\hline & 1 & 2 \\
\hline $\begin{array}{l}\text { Secondary education } \\
\text { enrollment }\end{array}$ & 108.59 & 94.42 \\
\hline $\begin{array}{l}\text { Tertiary education } \\
\text { enrollment }\end{array}$ & 98.40 & 59.36 \\
\hline $\begin{array}{l}\text { Quality of the } \\
\text { education system }\end{array}$ & 3.55 & 3.26 \\
\hline $\begin{array}{l}\text { Quality of math and } \\
\text { science education }\end{array}$ & 4.89 & 4.27 \\
\hline $\begin{array}{l}\text { Quality of } \\
\text { management schools }\end{array}$ & & \\
\hline $\begin{array}{l}\text { Internet access in } \\
\text { schools }\end{array}$ & 4.49 & 4.16 \\
\hline $\begin{array}{l}\text { Availability of } \\
\text { research and training } \\
\text { services }\end{array}$ & & \\
\hline $\begin{array}{l}\text { Extent of staff } \\
\text { training }\end{array}$ & 3.94 \\
\hline $\begin{array}{l}\text { Soure Authors } \\
\text { sea }\end{array}$ & 3.36 \\
\hline
\end{tabular}

Source: Authors' calculation

Table 6 shows the cluster membership. Even seven out of nine analysed Balkan countries belonged to the cluster with weaker performance (cluster 2). 
Table 6. Cluster Membership

\begin{tabular}{lcc}
\hline Case Number & Cluster & Distance \\
\hline Albania & 2 & 2.457 \\
\hline $\begin{array}{l}\text { Bosnia and } \\
\text { Herzegovina }\end{array}$ & 2 & 13.167 \\
\hline Bulgaria & 2 & 15.290 \\
\hline Croatia & 2 & 10.441 \\
\hline Greece & 1 & 15.657 \\
\hline Montenegro & 2 & 5.772 \\
\hline Romania & 2 & 6.588 \\
\hline Serbia & 2 & 2.586 \\
\hline Slovenia & 1 & 15.657 \\
\hline
\end{tabular}

Source: Authors' calculation

In addition to Greece and Slovenia, which were grouped in the first cluster, all other countries belonged to the cluster with lower performance in terms of the quality of higher education.

\subsection{Systematization of critical indicators within "Higher education and training" pillar in the Balkan countries}

In order to approach the improvement of the quality of higher education and create the conditions for education to become an important factor of the competitiveness of the Balkan countries, it is necessary to identify the areas that require improvement. The indicators of the first priority level were highlighted in Table 7 by the benchmarking analyses based on the values of indicators within the "Higher education and training" pillar for each Balkan country and the average values of indicator for the group of Balkan countries shown in Table 1. The average value of a particular indicator in the Balkan countries was used as benchmark. All indicators in a particular country whose value is less than the average of the group were indicated as indicators that require improvement. Namely, in addition to the fact that the overall quality level of higher education in the Balkan countries requires improvement, each country should first apply corrective measures and make improvements in indicators in which it deviates from the average of the comparable (Balkan) countries (Krstić and Stanišić, 2016, p. 102). These indicators were marked as indicators of the first level of priorities.

Table 7. Indicators within the "Higher education and training" pillar according to the priority of improvements in the observed countries

\begin{tabular}{lc}
\hline Country & $\begin{array}{c}\text { Indicators - the benchmark is } \\
\text { the average of the Balkan } \\
\text { countries }\end{array}$ \\
\hline Albania & $\mathrm{I}_{1}, \mathrm{I}_{2}, \mathrm{I}_{4}, \mathrm{I}_{7}$ \\
\hline $\begin{array}{l}\text { Bosnia and } \\
\text { Herzegovina }\end{array}$ & $\mathrm{I}_{1}, \mathrm{I}_{2}, \mathrm{I}_{3}, \mathrm{I}_{4}, \mathrm{I}_{5}, \mathrm{I}_{6}, \mathrm{I}_{7}, \mathrm{I}_{8}$ \\
\hline Bulgaria & $\mathrm{I}_{4}, \mathrm{I}_{5}, \mathrm{I}_{7}, \mathrm{I}_{8}$ \\
\hline Croatia & $\mathrm{I}_{3}, \mathrm{I}_{4}, \mathrm{I}_{6}, \mathrm{I}_{7}$ \\
\hline Greece & $\mathrm{I}_{3}, \mathrm{I}_{6}, \mathrm{I}_{7}, \mathrm{I}_{8}$ \\
\hline Montenegro & $\mathrm{I}_{1}, \mathrm{I}_{2}, \mathrm{I}_{4}, \mathrm{I}_{6}, \mathrm{I}_{8}$ \\
\hline Romania & $\mathrm{I}_{1}, \mathrm{I}_{2}, \mathrm{I}_{3}, \mathrm{I}_{5}, \mathrm{I}_{6}, \mathrm{I}_{8}$ \\
\hline Serbia & $\mathrm{I}_{1}, \mathrm{I}_{2}, \mathrm{I}_{3}, \mathrm{I}_{6}, \mathrm{I}_{8}$ \\
\hline Slovenia & $/$ \\
\hline
\end{tabular}

Source: Authors' calculation

Observed by countries, Bosnia and Herzegovina is the country with the lowest quality of higher education. All analysed education quality indicators in this country are identified as indicators that require improvement. The second weakest positioned country is Romania, in which six of the eight areas that determine the quality of higher education require improvement. These countries were followed by Serbia and Montenegro, in which five critical indicators were identified. In Albania, Bulgaria, Croatia and Greece, four critical indicators were separated. Slovenia, as a leader in the region with regard to the quality of higher education, had no critical indicators. Slovenia recorded the value of all indicators higher than the average of the Balkan countries.

Observed by indicators, "Internet access in schools" (I6) and "Extent of staff training" (I8) were separated as critical indicators in six out of nine analysed countries. The generally viewed, the Balkan countries should give priority to these two areas in the policy of improving the quality of higher education. 


\section{CONCLUSIONS}

Cross-country comparison highlighted Bosnia and Herzegovina as the country with the worst performances among the Balkan countries when it comes to both the quality of higher education and the level of competitiveness. On the other hand, Slovenia stood out as a leader in a selected group of countries. The calculated minimum, maximum and average values of the indicators within the "Higher education and training" pillar indicated that the Balkan countries lag behind the best world practice in terms of quality of higher education. By calculating the variation coefficient, it was noticed that the greatest variability and the unevenness of the achieved results among the Balkan countries existed when it comes to tertiary education enrollment.

Previous researches emphasized the existence of positive relationship between the quality of higher education and competitiveness, especially in developed countries (Şener and Sarıdoğan (2011); Pavlin and Svetlicic, 2012; Sekuloska, 2014; Keser, 2015; Aleksejeva (2016)). The results of the correlation analysis carried out in the paper indicated that there was no high positive correlation between the values of the GCI and the values of the analysed education quality indicators in the Balkan countries. In this way, the initial assumption of the research was rejected. It was not statistically confirmed that there is a relationship between the quality of education and the competitiveness of the Balkan countries, hinting that the expected positive benefits of quality of education might need more time to influence the competitiveness of these countries.

However, the Balkan countries achieved better results and values of the "Higher education and training" pillar compared to the GCI values. This suggested that, in addition to the fact that it is necessary to improve the quality of higher education in the Balkan countries, the special task is to use already achieved results in this field in order to improve the level of competitiveness. By the cluster analysis, the Balkan countries are grouped into two relatively homogeneous groups according to the indicators within the "Higher education and training" pillar. Even seven out of nine analysed countries (Albania, Bosnia and Herzegovina, Bulgaria, Croatia, Montenegro, Romania and Serbia) belonged to the cluster with the weakest performance. Improving the quality of higher education in these countries would contribute to a better positioning of the Balkan countries as a whole in global terms. Critical indicators of the quality level of higher education by countries that should have a priority in the improvement policy were separated by the benchmarking analysis, where the benchmark was the average of the group. "Internet access in schools" and "Extent of staff training" were stood out as particularly critical indicators for the group of Balkan countries as a whole. These indicators require special and urgent attention of the creators and implementers of education policy and strategy, development policy and competitiveness policy in the Balkan countries. General recommendations for the improvement of these areas of higher education could be following: higher allocations from the state budget for improvement quality of education and equipment of educational institutions; strengthening awareness of the importance of information literacy, which means not only potentially greater working capacity in the future, but also protection of children from different types of abuse that are exposed on the Internet; raising awareness about the necessity of lifelong learning having in mind the fact that the scope of information and available global knowledge daily increases and requires continuous learning. Education system must be able to withstand the galloping growth of the volume of world knowledge, that is why employees in educational institutions must be participants in daily and lifelong learning.

\section{ACKNOWLEDGEMENT}

The paper is part of the research at the projects 179066 "Improving the competitiveness of the public and private sector by networking competences in the process of the European integration of Serbia", financed by the Ministry of Education, Science and Technological Development of the Republic of Serbia.

\section{Conflict of interests} interest.

The authors declare no conflict of

\section{REFERENCES}

Aleksejeva, L. (2016). Country's competitiveness and sustainability: higher education impact. Journal of Security and Sustainability Issues, 5(3), 355363. http://dx.doi.org/10.9770/jssi.2016.5.3(4)

Balkyte, A., \& Tvaronavičiene, M. (2010). Perception of competitiveness in the context of 
sustainable development: facets of "sustainable competitiveness". Journal of business economics and management, 11(2), 341-365. https://doi.org/10.3846/jbem.2010.17

Cremin, P., \& Nakabugo, M. G. (2012). Education, development and poverty reduction: A literature critique. International Journal of Educational Development, 32(4), 499-506. https://doi. org/10.1016/j.ijedudev.2012.02.015

Cretan, G. C., \& Gherghina, R. (2015). Funding higher education in a few EU countries: Implications for competition and competitiveness in higher education. Journal of Knowledge Management, Economics and Information Technology, 5(1), 1-22. http://citeseerx.ist.psu.edu/viewdoc/downl oad?doi=10.1.1.685.3886\&rep $=$ rep1\&type $=$ pdf

Đurić, D., Mitrović, V., Đurić, D., \& Ristić, J. (2018) Strengthening international competitiveness and investment growth as the basis for a new model of Serbian economy development. Economics of Agriculture, 65(2), 731-744. https://doi. org/10.5937/ekoPolj1802731D

Fonseca, L., \& Lima, V. (2015). Countries three Wise Men: Sustainability, Innovation, and Competitiveness. Journal of Industrial Engineering and Management, 8(4), 1288-1302. http://dx.doi.org/10.3926/jiem.1525

Fonseca, L. M., Portela, A. R., Duarte, B., Queirós, J., \& Paiva, L. (2018). Mapping higher education for sustainable development in Portugal. Management \& Marketing. Challenges for the Knowledge Society. 13(3), 1064-1075. https:// doi.org/10.2478/mmcks-2018-0023

Hebibi, L., Raimi, N., \& Milićević, R. (2019). Knowledge management and the importance of knowledge management for the organization's performance. Ekonomika, 65(1), 117-126. https://doi.org/10.5937/ekonomika1901117H

Kabók, J., Kis, T., Csüllög, M., \& Lendák, I. (2013). Data envelopment analysis of higher education competitiveness indices in Europe. Acta Polytechnica Hungarica, 10(3), 185-201. Retrieved from https://www.uni-obuda.hu/ journal/Kabok_Kis_Csullog_Lendak_41.pdf

Keser, H. Y. (2015). Effects of higher education on global competitiveness: reviews in relation with European countries and the middle east countries. Annals of' Constantin Brancusi 'University of Targu-Jiu. Economy Series, 1(1), 58-68. Retrieved from http://www.utgjiu. $\mathrm{ro} / \mathrm{revista} / \mathrm{ec} / \mathrm{pdf} / 2015-01$.Volumul\%201/08 Hilal\%20Yildirir.pdf

Kovaleva, N. I., Valeyeva, N. S., Avilova, N. L., Kharisova, G. M., Khayrutdinov, R. R., Khairullin, E. R., \& Shaikhlislamov, A. K. (2015). Recommended practices for improving the competitiveness of the Russian education services market under the conditions of the international educational integration. Review of European Studies, 7(4), 1-5. http://dx.doi. org/10.5539/res.v7n4p1

Krstić, B., \& Stanišić, T. (2013). The influence of knowledge economy development on competitiveness of southeastern Europe countries. Industrija, 41(2), 151-167. doi:10.5937/industrija41-4000

Krstić, B., \& Stanišić, T. (2016). Zdravstvo i osnovno obrazovanje kao determinantne konkurentnosti privrede Republike Srbije. [Health and primary education as determinants of competitiveness of the Serbian economy]. In B. Krstić (Ed.), Faktori konkurentnosti Republike Srbije [Factors of competitiveness of the Republic of Serbia] (pp. 87-106). University of Niš, Faculty of Economics.

Krstić, B., Petrović, J., \& Stanišić, T. (2015). Influence of education system quality on the use of ICT in transition countries in the age of information society. TEME, 39(3), 747-763. Retrieved from http://teme2.junis.ni.ac.rs/index.php/TEME/ article/view/75/43

Lane, J. E. (2012). Higher education and economic competitiveness. In Lane J. E. and Bruce J.D. (Eds.) *Universities and colleges as economic drivers: Measuring higher education's role in economic development* (pp. 1-30). Albany: State University of New York Press.

Lauder, H., Brown, P., Dillabough, J. A., \& Halsey, A. H. (2006). Education, globalization, and social change. Oxford university press. Retrieved from https://researchportal.bath.ac.uk/en/ publications/education-globalization-andsocial-change

Mason, R. D., Lind, D. A., \& Marchal, W. G. (1983). Statistics: an introduction. New York: Harcourt Brace Jovanovich.

Mayo, P. (2009). Competitiveness, diversification and the international higher education cash flow: the EU's higher education discourse amidst the challenges of globalisation. International Studies in Sociology of Education, 19(2), 87-103. http:// dx.doi.org/10.1080/09620210903257174

Miller, D. L. (2013). Universities and Colleges as Economic Drivers: Measuring Higher Education's Role in Economic Development (Book Review). Planning for Higher Education, 41(4), 135-137. Retrieved from https://search.proquest.com/openview/056 fb835c0bf2566681bde9a9bc92949/1?pqorigsite $=$ gscholar $\& \mathrm{cbl}=47536$

Pavlin, S., \& Svetlicic, M. (2012). Higher education, employability and competitiveness. Hacettepe Üniversitesi Eğitim Fakültesi Dergisi, 43(43), 386-397. https://eric.ed.gov/?id=EJ979698

Persaud, A. (2017). Integrated planning for education and development. European Journal of Education, 52(4), 448-459. https://doi. org/10.1111/ejed.12233

Petrović, P., \& Živković, D. (2017). Continuing education of hotel employees and their shared vision of the organization. Menadžment $u$ hotelijerstvu $i$ turizmu - Hotel and Tourism Management, 5(1), 85-93. Retrieved from http:// www.htmanagementvb.com/index.php/HITM/ article/view/29

Puška, A., \& Beganović, A. I. (2016). Primjena klaster analize u ekonomskim istraživanjima [The Implementation of Cluster Analysis in Economic Research]. Oeconomica Jadertina, 6(1), 3-19. Retrieved from https://hrcak.srce.hr/168460

Radovanović, V., \& Rendulić, V. (2017). With knowledge and innovation in new tourism venture. Menadžment $u$ hotelijerstvu i turizmu Hotel and Tourism Management, 5(2), 96-105. Retrieved from http://www.htmanagementvb. com/index.php/HITM/article/view/12

Schofer, E., \& Meyer, J. W. (2005). The worldwide expansion of higher education in the twentieth century. American Sociological Review, 70(6), 898-920, https://doi. 
org/10.1177/000312240507000602

Sekuloska, J. D. (2014). Higher education and training as crucial pillars in creating the competitiveness of nation. Procedia-Social and Behavioral Sciences, $156(26), \quad 241-246 . \quad \mathrm{https}: / /$ doi. org/10.1016/j.sbspro.2014.11.182

Şener, S., \& Sarıdoğan, E. (2011). The effects of sciencetechnology-innovation on competitiveness and economic growth. Procedia-Social and Behavioral Sciences, 24, 815-828. https://doi. org/10.1016/j.sbspro.2011.09.127

Stanišić, T., \& Leković, M. (2018). ICT readiness as a factor of tourism competitiveness. In D. Cvijanović et al. (Eds.), Tourism in Function of Development of the Republic of Serbia - Tourism in the Era of Digital Transformation (pp. 390406). University of Kragujevac, Faculty of Hotel Management and Tourism in Vrnjačka Banja. Retrieved from http://www.tisc.rs/proceedings/ index.php/hitmc/article/view/23

Stonkiene, M., Matkeviciene, R., \& Vaiginiene, E. (2016). Evaluation of the national higher education system's competitiveness: Theoretical model. Competitiveness Review, 26(2), 116-131. https://doi.org/10.1108/CR-06-2015-0055
Stošić, L. (2015). The importance of educational technology in teaching. International Journal of Cognitive Research in Science, Engineering and Education (IJCRSEE), 3(1), 111-114. http:// www.ijcrsee.com/index.php/ijcrsee/article/ view/122

Sum, N.-L., \& Jessop, B. (2013). Competitiveness, the knowledge-based economy and higher education. Journal of the Knowledge Economy, $4(1), \quad 24-44$. https://doi.org/10.1007/s13132012-0121-8

Taylor, R. (1990). Interpretation of the Correlation Coefficient: A Basic Review. Journal of Diagnostic Medical Sonography, 6(1), 35-39. https://doi.org/10.1177/875647939000600106

Van der Wende, M. C. (2000). The Bologna Declaration: Enhancing the transparency and competitiveness of European higher education. Journal of Studies in International Education, 4(2), 3-10. https:// doi.org/10.1177/102831530000400202

Weber, J. C., \& Lamb, D. R. (1970). Statistics and Research in Physical Education. St. Louis: CV Mosby Co.

WEF. (2017). The Global Competitiveness Report 2017-2018. World Economic Forum, Geneva.

\section{ANNEX 1}

Descriptive statistics (World countries)

\begin{tabular}{|c|c|c|c|c|c|c|}
\hline & $\mathrm{N}$ & Minimum & Maximum & Mean & $\begin{array}{c}\text { Std. } \\
\text { Deviation }\end{array}$ & $\begin{array}{l}\text { Variation } \\
\text { Coefficient } \\
\quad(\%)\end{array}$ \\
\hline Secondary education enrollment, gross $\%$ & $134^{*}$ & 22.40 & 166.81 & 86.92 & 28.34933 & 32.61 \\
\hline Tertiary education enrollment, gross $\%$ & $134^{* *}$ & 0.80 & 113.87 & 43.38 & 28.07921 & 64.72 \\
\hline Quality of the education system, 1-7 (best) & 137 & 1.85 & 6.19 & 3.77 & 0.92085 & 24.42 \\
\hline $\begin{array}{l}\text { Quality of math and science education, 1-7 } \\
\text { (best) }\end{array}$ & 137 & 2.27 & 6.46 & 4.05 & 0.93487 & 23.06 \\
\hline Quality of management schools, 1-7 (best) & 137 & 2.58 & 6.39 & 4.30 & 0.83404 & 19.41 \\
\hline Internet access in schools, $1-7$ (best) & 137 & 1.59 & 6.18 & 4.26 & 1.01875 & 23.89 \\
\hline $\begin{array}{l}\text { Availability of research and training } \\
\text { services, } 1-7 \text { (best) }\end{array}$ & 137 & 2.39 & 6.68 & 4.45 & 0.82178 & 18.46 \\
\hline Extent of staff training, 1-7 (best) & 137 & 2.29 & 5.75 & 4.04 & 0.70382 & 17.42 \\
\hline \multicolumn{7}{|c|}{$\begin{array}{l}\text { Legend: There is no data on the "Secondary education enrollment" indicator in the Global Competitiveness } \\
\text { Report } 2017-2018 \text { for } 3 \text { out of the } 137 \text { analyzed world countries (Haiti, Trinidad and Tobago and United Arab } \\
\text { Emirates) }\end{array}$} \\
\hline
\end{tabular}

2017-2018 for 3 out of the 137 analyzed world countries (Haiti, Nicaragua and Sierra Leone).

Source: Authors' calculation 